\title{
İlk ve Ortaokul Yöneticilerinin Çatışma Yönetimi Stilleri İle Benlik Saygısı Arasındaki İlişkinin İncelenmesi ${ }^{1}$
}

\author{
Ezgi Nurbahar ŞANLI-GÜNEŞ ${ }^{2}$ ve Ahmet AKBABA ${ }^{3}$
}

\section{Öz}

Çalışma, ilk ve ortaokullarda görev yapan okul yöneticilerinin çatışma yönetimi stilleri ile benlik saygısı arasındaki ilişkinin belirlenmesi amacıyla yapılııştır. Araştırma evrenini; Antalya ilindeki ilk ve ortaokul yöneticileri, çalışma örneklemini ise Serik ve Manavgat ilçeleri ilk ve ortaokul yöneticileri oluşturmaktadır. Serik ve Manavgat ilçelerinde 179 resmi ilk ve ortaokullarda görev yapan okul yöneticilerinden 241 kişinin katılımı ile araştırma gerçekleştirilmiştir. Araştırmada veri toplama aracı olarak "Kişisel Bilgi Formu", "Trakya Üniversitesi Benlik Sayg1sı Ölçeği (TÜBSÖ)" ve "Rahim Örgütsel Çatışma Ölçeği” kullanılmıştır. Araştırmada verilerin analizinde yüzde, aritmetik ortalama, standart sapma testi, t-testi, tek yönlü ANOVA testi, Tukey testi kullanılmıştır. Araştırma sonucunda; Okul yöneticilerin benlik saygısı ile kaçınma ve hükmetme stillerini kullanmaları arasında da ilişki görülmüş, yüksek benlik saygısına sahip bireylerin özellikleri ile tümleştirme ve uzlaştırma stilleri arasında anlamlı bir kolerasyon bulunmamıştır. Katılımcıların en çok tercih ettikleri çatışma yönetim stili tümleştirme, uzlaşma ve ödün verme olurken en az kullandıkları stil hükmetme ve kaçınma olmuştur. Aynı zamanda yüksek benlik saygısına sahip bireylerin özelliklerine ters düşen özellikler taşıyan ödün verme, kaçma ve hükmetme arasında ilişki bulunduğu gibi sonuçlara ulaşılmıştır.

Anabtar Kelimeler: Çatışma, Çatışma yönetim stili, Benlik, Benlik saygısı, Yönetici

\section{Examining the Relationship between Conflict Management Styles and Self-Esteem of Primary and Secondary School Administrators}

\begin{abstract}
The study was conducted to determine the relationship between conflict management styles and self-esteem of school administrators working in primary and secondary schools. The research universe is composed of the primary and secondary school managers in Antalya province and the study universe consists of the primary and secondary school managers in Serik and Manavgat districts. In Serik and Manavgat districts, research was carried out with the participation of 241 people from the school administrators working in 179 official primary and secondary schools. In research as a data collection tool "personal information form", "Trakya University self-esteem scale" and "Rahim organizational conflict Scale" were used. Research, Data Analysis, Percentage, arithmetic mean, standard deviation, ttest, one-way ANOVA test, Tukey test was used. Conflict management styles and self-esteem of the managers have been determined. Conflict management styles and self-esteem scale values used by school principals; age, gender, branch, year of service, year of service as administrator, income group, number of teachers and support staff at school were analyzed. However, the relationship between self-esteem scale values and conflict management styles of school principals was analyzed. As a result of the research; There was also a relationship between school principals' self-esteem and avoidance and dominance styles. No significant correlation was found between characteristics of individuals with high self-esteem and integration and mediation styles. The most preferred conflict management style of the participants was integration, reconciliation and compromise, while the least preferred style was dominance and avoidance. At the same time, the results have been reached such that there is a relationship between compromising, escaping and dominating which have characteristics that contradict the characteristics of individuals with high selfesteem.
\end{abstract}

Key Words: Conflict, Conflict management style, Self-concept, Self-esteem, Management

\section{Atıf İçin / Please Cite As:}

Şanl1-Güneş, E. N. ve Akbaba, A. (2020). İlk ve ortaokul yöneticilerinin çatışma yönetimi stilleri ile benlik sayg1sı arasındaki ilişkinin incelenmesi. Manas Sosyal Araştırmalar Dergisi, 9(3), 1410-1425.

Geliş Tarihi / Received Date: 24.09.2019

Kabul Tarihi / Accepted Date: 22.04.2020

\footnotetext{
${ }^{1}$ Bu makale ikinci yazarın danışmanlığında tamamlanan yüksek lisans tezinden türetilmiştir.

2 Yüksek Lisans Öğrencisi - Van Yüzüncü Y1l Üniversitesi, ezgigunes29@gmail.com - ORCID: 0000-0003-4335-6720

3 Doç. Dr. - Van Yüzüncü Yıl Üniversitesi Eğitim Fakültesi, ahmetakbaba13@gmail.com - ORCID: 0000-0003-3256-441X
} 


\section{Giriş}

Demokratik yönetim tarzını seçen Örgütlerde çatışma olmazsa olmaz durumlardan biridir. Daha iyiyi bulmak yönetimin gayesi haline gelmişse her zaman alternatif çözüm yolları da olacaktır. Bu çözüm yollarından birisin her zaman seçmek kolay olmamakta alternatifler arasında tercih belirleme gerilime ve çatışmaya neden olabilmektedir. Çatışma böyle durumlarda kaçınılmaz bir olgu olarak ortaya çıkabilmektedir.

Eğitimcilerin ortak olarak kabul ettiği eğitime bakış açısına göre eğitimi oluşturan üç temel faktör: aile ortamı, çevre ve okul bir çocuğun eğitiminde başrol oynamaktadır. Bu üç önemli faktörden biri eksik olduğumda çocuğun yetişmesi de eksik olur (Yaşar, 2020, S. 2164). Okul, önce kişiliğin şekillendiği, kalıc1 davranış değişikliklerinin oluşturulduğu bir yerdir. Okulda tüm iç ve dış paydaşları ortak bir amaç doğrultusunda birleştiren, rehberlik eden, yöneten, okul yöneticisidir. Okul yöneticisi lider konumdadır. Eğer okullar ve üniversiteler iyi yönetilirse, öğrencilerine kaliteli eğitim sağlamakta daha etkin olurlar. Bu sebeple eğitim kurumlarında etkin yönetimin önemini daha fazla artmaktadır. Eğitim kurumlarında liderliğin, yönetimin rastlantılara bırakılmaması gerekir (Bridge, 2003. S 1). Okulların informal yönleri formal yönlerinden daha baskındır. Bu nedenle okul müdürlerinin kişilik yapıları, tutum ve davranışları, becerileri okulun işleyişine etki etmektedir. Lider konumunda olan okul yöneticisinin davranışlarının etkililik derecesi, okulunun amaçlarını gerçekleştirmesinde olumlu katkı sağlayacaktır.

Çatışma: Çatışma kavramı yaşamın her alanında sıkça karşılaşılan ve çoğu zaman insanların çatışma olgusunu yönetmek için yeni yol ve yöntemler geliştirdiği bir süreç yönetimini ifade eder. Çatışma aslında anlaşmazlık ürünü gerilim anlamına da gelir. Sürecin nasıl yönetileceği konusu çatışma sonrası hangi sonucun ortaya çıkacağının belirlendiği bir aşamadır. Çatışma olgusu nerdeyse tüm organizasyonların üzerinde durduğu ve örgütün devamını sağlamanın ön koşulu olduğu söylenebilir. Çatışma iki ya da daha fazla birey arasında çeşitli nedenlerden kaynaklanan anlaşmazlık olarak tanımlanabilmektedir (Erçetin, 2000, s. 377).

Çatışma Türleri; Çatışma birçok alanı içine alan ve üzerinde birçok tanımlama yapılan bir kavram olarak karşımıza çıkmaktadır. Çatışma türlerini Koçel (2007, s. 507), niteliğine, ortaya çıkış şekline, taraflar açısından ve organizasyon içindeki yerine göre sınıflandırmıştır. Benliğin gelişimi, uyum ve sürekliliği, bireyin benlik saygisına bağlıdır. Benliğin var olması için birey, çevre ve kendisi tarafından kabul edilmeli, değer görmeli ve saygın olmalıdır. Ancak benliğinin gelişimi sürecinde, kendisiyle ilgili olumlu uyaranlar alan birey, kendisini değerli görerek kendisine saygı duyar. Bu açıdan bakıldığında benlik kavramının belki de en önemli bölümünü benlik saygısı oluşturmaktadır. Benlik saygısı ve başarı arasında önemli bir ilişki olduğu söylenmektedir. "Bireyin benlik saygısının yüksek olması $\mathrm{m}$ onun başarısını ve çevresiyle olan olumlu ilişkilerini etkilemektedir, yoksa başarıları ve çevresiyle olan olumlu ilişkiler neticesinde mi benlik saygısı artmaktadır? Sorusunun kuşkusuz her iki cevabı da doğrudur ve birbirini etkilemektedir. Benlik saygisı yüksek olan bireyin benlik imajının da olumlu olacak buna bağlı olarak birey yeteneklerine güvenerek girişimde bulunabilecek ve aynı zamanda başarı düzeyini yükseltecektir. Başarılı olan bireyler kendine güveni artacak ve benlik imajı da olumlu yönde gelişerek benlik saygısı yükselecektir. Okul farklı benlik yapılarını barındıran insanların bir arada bulunduğu bir örgüttür. Farklı kişilik yapıları, değerler, inançlar, kültürlerin okul ortamında dengede kalıp uzlaşması gerekir. Bu nedenle okul yöneticileri çatışma yönetiminde yeterlilik sahibi olmalıdır.

Okulda tüm iç ve dış paydaşları ortak bir amaç doğrultusunda birleştiren, rehberlik eden, yöneten, okul yöneticisidir. Okul yöneticisi lider, yönetici konumundadır. Okulların informal yönleri, formal yönlerinden daha baskındır. Bu nedenle okul yöneticilerinin kişilik yapıları, tutum ve davranışları, becerileri okul ile ilgili iş ve işlemlerin yürütülmesine etki etmektedir. Lider, yönetici konumunda olan okul yöneticisinin davranışlarının etkililik derecesi, okulunun amaçlarını gerçekleştirmesine olumlu katkı sağlamaktadır. Okul yöneticilerinin, okulda yüksek motivasyon ve iş doyumu içinde çalışabilmesi için fiziki sağlıklarının yanında ruh sağlı̆̆ı açısından sağlıklı olması gerekir. Okul yöneticilerinin benlik saygısı yüksek bireyler olması, okul performansı etkileyecektir. Kapsam olarak ele alındığında benlik ile benlik saygısı benzer unsurlar olmasına rağmen, benlik kavramının benimsenmesi (beğenilmesi) veya benimsenmemesi (beğenilmemesi) benlik saygısı kavramını ortaya çıkarmaktadır. Bireylerin kendilerinde tanımladığı bütün değerleri, olumlu düşünceleri, kendilerine yükledikleri önemlilik alg1sı, saygı görme duygusu benlik saygısını kapsamaktadır. Benlik kavramının kabul edilmesi yani benimsenmesi benlik saygisını meydana getirmektedir. Benlik saygısı, benliğin gelişmesinin önemli yönlerinden birisi olarak görülmektedir. Çünkü kendi kişilik ve yeteneklerimize dair değerlendirmelerimiz, duygusal tecrübeleri, ilerideki davranışları ve 
uzun vadeli psikolojik entegrasyonu etkilemektedir. Benlik sayg1sı özünde kendine değer verme ve kendisiyle alakalı gerçekçi değerlendirmeler ve çözümlemeler yaparak iyisiyle ve kötüsüyle bunları kabullenerek bunlarla barışık olmakla alakalı bir kavramdır. Okul müdürlerinin, yüksek benlik saygısına sahip olması, çatışma yönetiminde yetkin olması, okulda insan ilişkilerini, öğretmen ve öğrencilerin sosyal ve duygusal gelişmelerine yardım ederek onların kabul görme, takdir edilme, kendini gerçekleştirme gibi temel ihtiyaçlarına cevap verecek dengeli bir kişilik geliştirmelerine olanak sağlayacaktır. Benlik saygısı, kişinin kendisini başarıll, sevilen, değer verilen bir birey olarak görme derecesini yansıtmaktadır. Bu noktada okul liderlerinin benlik saygısı algısının yüksek olması okul içi ilişkilerin olumlu şekillenmesine de olanak sağlayacaktır. Bireyin söz edilen faktörler açısından kendini yeterli görme eğilimi, istenilen yani olumlu bir kişilik özelliği işaretidir.

Literatürde eğitim yöneticilerinden beklenen ve istenilen niteliklere bakıldığında; eğitim yöneticilerinin iletişim becerisi yetenekleri yüksek, insiyatif alıp verebilen, denetleyen ve bütünleyen, problem çözebilen, yaratıcı ve aynı zamanda yeniliklere adapte olabilen, problem çözebilen öğretim liderliğini üstlenen bireyler olması gerekliliği üzerinden durulmuştur (Özdemir, 1998, s. 67). Kendini tanıan, potansiyelini kullanabilen, sınırlarını bilen, olumlu olumsuz yönlerinin farkında olan bir eğitim yöneticisi, bulunduğu kurumu en verimli şekilde kullanacaktır. Aynı zamanda eğitim yöneticileri okullarda yaşanan çatışmaları, okulun yararına çözümleyip, çatışma türlerini belirleyip, çatışmaları nasıl yöneteceklerini, yönetirken hangi çözüm yöntemleri kullanacaklarını bilmeleri gerekir. Bu araştırma, okul yöneticilerinin çatışma yönetme stillerine ve benlik saygılarına ilişkin algılarını yönetici bakış açısıyla inceleyecektir. Bu algılarla bazı değişkenler arasında anlamlı farklılıkların bulunup bulunmadığını ortaya çıkarmak okulun yönetim yapısına olumlu etkiler yapacağı ve yönetilen guruplara da üstleri hakkında ipuçları vermesi açısından önemlidir. Türkiye'de benlik saygisı ve çatışma yönetimi stilleri konusunda ayrı ayrı çalışmalar yapıllmıştır. Fakat bu iki konuyu bir arada içeren bir çalı̧smaya rastlanmamıştır. Bu nedenle böyle bir araştırma yapılması planlanmıstır.

$\mathrm{Bu}$ araştırmada, ilkokul ve ortaokullarında görev yapan yöneticilerin çatışma yönetim stillerinin nasıl bir dağılım gösterdiği, benlik saygılarının düzeyleri ve çatışma yönetim stilleri ile benlik saygısı arasındaki ilişki incelenmiştir. Bu algılarla ilkokul ve ortaokullarında görev yapan yöneticilerin çatışma yönetim stillerinin nasıl bir dağılım gösterdiği bazı değişkenler arasında anlamlı farklılıkların bulunup bulunmadığını ortaya çıkarmak okulun yönetim yapısına olumlu etkiler yapacağı ve yönetilen guruplara da üstleri hakkında ipuçları vermesi eğitim yöneticileri ve planlamacılarına öneriler sunulması araştırmanın önemini ortaya koymaktadır.

\section{Amaç}

$\mathrm{Bu}$ araştırmanın amacını; İlkokul ve ortaokullarında görev yapan yöneticilerin çatışma yönetim stillerinin nasıl bir dağılım gösterdiği, benlik saygılarının düzeyleri ve çatışma yönetim stilleri ile benlik saygısı arasındaki ilişsinin belirlenmesi oluşturmaktadır.

1. Okul yöneticilerin çatışma stilleri nasıldır?

2. Okul yöneticilerinin; çatışma yönetim stilleri ile Cinsiyet, Yaş, Branş, Gelir grubu, Meslekte geçen süre, Meslekte yönetici olarak geçen süre, Okuldaki destek personeli, arasında ilişki var mıdır?

3. Okul Yöneticilerin benlik saygisı ne düzeydedir?

4. Okul yöneticilerinin çatışma yönetim stilleri ile benlik saygısı arasındaki Cinsiyet, Yaş, Branş, Gelir grubu, Meslekte geçen süre Meslekte yönetici olarak geçen süre, Okuldaki destek personeli, arasında ilişki var mıdır?

5. Okul Yöneticilerin çatışma yönetimi stilleri ve benlik saygısı arasında ilişki durumu nasıldır?

\section{Yöntem}

Araştırmanın bu bölümünde araştırma modeli, evren ve örneklem, veri toplama tekniği ve analizi açıklanmışır. Ayrıca bu bölümde araştırmada kullanılan çatışma yönetim stilleri ölçeği ve benlik saygısı ölçeği ile ilgili bilgilere yer verilmiştir.

\section{Araştırma Modeli}

İlkokul ve ortaokul yöneticilerinin çatışma yönetimi stilleri ile benlik saygısı arasındaki ilişkiyi belirlemeyi amaçlayan bu araştırma, var olan durumu incelediğinden betimsel ve ilişkisel tarama modeli kullanılan (Büyüköztürk vd. 2009, s. 39; Erkuş, 2005, s. 56; Karasar, 2002, s. 89), bir çalışmadır. Bu araştırmada, ilkokul ve ortaokul yöneticilerinin benlik saygısı ve çatışma yönetme stilleri arasındaki ilişki 
incelenmiştir. Ayrıca yöneticilerin; cinsiyet, yaş, branş, öğretmen olarak hizmet y1lı, eğitim yöneticisi olarak hizmet yılı, okul destek personeli ve algıladıkları gelir düzeylerine göre farklılık gösterip göstermediğini incelemek amaçlandığından, bu amaca en uygun model olan genel tarama modeli kullanılmıştır.

\section{Evren - Örneklem}

Araştırma evrenini Antalya ilindeki ilk ve ortaokulları yöneticileri, çalışma örneklemini ise evrenin temsil edebilecek büyüklüğe sahip Serik ve Manavgat ilçelerindeki ilk ve ortaokul yöneticilerinin tamamı oluşturmaktadır. Serik ve Manavgat ilçelerinde 179 resmi ilk ve ortaokullarda görev yapan okul yöneticilerinden 241 kişinin katılımı ile araştırma gerçekleştirilmiştir. Araştırmada evrenin tamamına ulaşılmaya çalışılmıştır.

\section{Verilerin Toplanması ve Analizi}

$\mathrm{Bu}$ araştırmada veri toplamak için tarama modelinde genellikle kullanılan tekniklerden biri olan anket (survey) tekniği kullanılmıştır. Karasar (2012, s. 89) tarafindan, geçmişte ya da halen var olan bir durumu var olduğu biçimiyle betimlemeyi amaçlayan ve araştırmaya konu olan olay, birey veya nesneyi, kendi koşulları içerisinde olduğu gibi tanımlamaya çalışan model olarak betimlenen, tarama modeli kullanılmıştır. Araştırmada kullanılan veri toplama aracı olan anket üç ayrı bölümden oluşmakta olup ilk bölümde kişisel bilgi formu, ikinci bölümde Rahim Örgütsel Çatışma Ölçeği ve üçüncü bölümde ise benlik sayg1sı ölçeği kullanılmıştır.

Anketin birinci bölümünde yer alan kişisel bilgi formunda; cinsiyet, yaş, öğretmenlik branş1, öğretmen olarak hizmet y1l, eğitim yöneticisi olarak hizmet y1l, okuldaki destek personeli, ilişkin bilgiler yer almaktadır. Anketin ikinci bölümünde "Rahim (1983) tarafından geliştirilen Örgütsel Çatışma Ölçeği” kullanılmıştır. Örgütsel çatışma ölçeği 28 sorudan oluşmakta olup 5 alt boyutta ele alınmış olup bu boyutlar; tümleştirme (bütünleştirme), ödün verme (uyma), hükmetme, kaçınma ve uzlaşmadır. Yöntemlerin kullanılma düzeyleri olarak "her zaman" 5, "çoğunlukla" 4, "ara sıra" 3, "az" 2 ve "hiçbir zaman” 1 şeklinde puanlanmıştır.

Okul yöneticilerinin çatışma yönetimi yöntemlerinin ne düzeyde kullandığını ölçebilmek üzere Gümüşeli (1994) tarafından Türkçeye uyarlanmış olan ölçek, çalışmada kullanılmıştır. Araştırmada çatışma yönetim stilleri ile ilgili alt boyutlarına ilişkin Cronbach's Alpha değerleri hesaplanmıştır. Güvenirlik analizi sonucuna göre Cronbach's Alpha katsayısı \%95 güven aralığında genel olarak 0,70 ve üzeri ç1kmış olup, çalışma bu güven aralığında analiz edilmiştir. Tabloda verilen Cronbach's Alpha değeri incelendiğinde ölçeğin güvenir olduğu, istatistik tutumlarının belirlenmesinde güvenirlik düzeyi yüksek ölçme sonuçlarının elde edilebileceğini göstermektedir. Anketin üçüncü bölümünde Arıcak (2001) tarafindan geliştirilen "Trakya Üniversitesi Benlik Saygısı Ölçeği” (TÜBSÖ) kullanılmıştır. Kullanılan ölçekte 32 soruluk beşli Likert tipi bir tutum ölçeği anketi sorularına yer verilmiştir. Anket sorularına verilen cevap seçenekleri "tamamen katılıyorum, katılıyorum, kararsızım, katılmıyorum, kesinlikle katılmıorum" şeklindeki sıralanmiştır.

Araştırma sorularından SPSS programında analize uygun olanlar frekans, ortalama standart sapma, varyans, ANOVA testi, T testi, Tukey testi Ki-kare testi (Chi Scuare, gibi testler kullanilarak analiz edilecek olup anketin güvenilirliğini Alfa kat sayısı p $>0.05$ anlamlı olarak kabul edilerek incelenmiştir. Benlik saygısı ölçeği 32 sorudan oluşmakta olup 1 ile 5 arasında değişen (Tablo-5) puan verilerek, 32 ile 160 arasında toplam puan aralığ1 belirlenmiştir. Puanlamada 19 madde tersten (reverse) puanlanmaktadır. Puanların yükselmesi benlik saygısı düzeyinin yükseldiğini; puanların azalması benlik saygısı düzeyinin düştüğünü ifade etmektedir.

Güvenirlik analizi sonucuna göre Cronbach's Alpha katsayısı \%95 güven aralığında genel olarak 0,92 ve üzeri çıkmış olup, çalışma bu güven aralığında analiz edilmiştir. Sosyal bilimler alanında yapılan çalışmalarda normallik testi özellikle beşli likert anketlerinde verilerin normal dağlım göstermesi oldukça zordur. Normallik testi özellikle temel bilimler alanında oldukça kabul gören bir test olarak karşımıza çıkmaktadır. Örneğin, beyindeki nöron sayısı, kan değerleri gibi değerlerin normal dağılım göstermesi beklenir. Sosyal bilimlerde Morga, Leech, Gloeckner ve Barrett (2011, s. 51), çarpıklık ve basıklık değeri üzerinden normallik testinin belirlenmesi gerektiğini belirtmişlerdir. Normallik testinin hesaplanmasında Kolmogorov-Smirnov ve Shapiro- Wilk testi analizlerinin kullanılmasının özellikle sosyal bilimler alanında en çok kullanılan yöntemlerden biridir. Kolmogorov-Sminnov ve Shapiro-Wilk değerlerinin -2 ve +2 değeri arasında yer alması verilerin normal dağılım gösterdiğini belirttiği ifade edebilir (Gravetter ve 
Wallnau, 2014). Çatışma yönetim stillerinin ve benlik saygısı değerleri arasındaki ilişkinin belirlenmesi ile ilgili araştırma sonucu elde edilen verilerle ilgili Kolmogorov- Smirnov ve Shapiro-Wilk testleri yapılmıştır. Yapılan analizler incelendiğinde çatışma yönetim stilleri ile ilgili olan anket soruları Kolmogorov-Smirnov ve Shapiro-Wilk testleri verilerinin alt sınır -0,914 ve üst sinır 0,157 olarak gerçekleştiği görülmektedir. Benlik sayg1sı ile ilgili olan anket soruları Kolmogorov-Smirnov ve Shapiro-Wilk testleri verilerinin alt sınır -0,458 ve üst sınır 0,312 olarak gerçekleştiği görülmektedir.

\section{Bulgular}

Araştırmanın bu bölümünde katılımcılara ait kişisel bilgilere yer verilmiş olup okul yöneticilerinin çatışma yönetim stilleri ve benlik saygısına ilişkin bulgulara yer verilmiştir.

\section{Kat1lımcı Özellikleri}

Araştırmaya katılan okul yöneticilerinin özelliklerine ilişkin veriler analiz edilmiştir. Okul yöneticilerinin cinsiyetleri, yaşları, branşları, hizmette geçen süre, hizmette yönetici olarak geçen süre, gelir durumu, okulda çalışan öğretmen sayısı, durumuna ilişkin veriler analiz edilmiş ve aşağıdaki tabloda verilmiştir.

Tablo 1. Katılimcı Özellikleri $(n=45)$

\begin{tabular}{|c|c|c|c|c|c|c|c|c|}
\hline Cinsiyet & $\mathbf{n}$ & $\%$ & Yaş & $\mathbf{n}$ & $\%$ & Hizmet Y1l & $\mathbf{n}$ & $\%$ \\
\hline Kadin & 9 & 20,0 & $25-35$ yaş & 13 & 28,9 & $1-5$ & 2 & 4.4 \\
\hline \multirow[t]{4}{*}{ Erkek } & 36 & 80,0 & $36-40$ yaş & 23 & 51,1 & $6-10$ & 7 & 15,6 \\
\hline & & & $41-50$ yaş & 5 & 11,1 & $11-15$ & 18 & 40,0 \\
\hline & & & 51 ve üstü yaş & 4 & 8,9 & $16-20$ & 14 & 31,1 \\
\hline & & & & & & 21 ve üstü & 4 & 8,9 \\
\hline
\end{tabular}

\section{Yöneticilerinin Çatışma Yönetim Stilleri}

Bu bölümde Okul Yöneticilerinin Çatışma Yönetim Stilleri davranış biçimlerine ilişkin bulgulara yer verilmiştir.

Tablo 2. Catısma Yönetim Stilleri Alt Boyutlar Betimsel İstatistikler ve Sonuclar

\begin{tabular}{llllll}
\hline & N & Toplam soru ağılrlı̆ $\mathbf{1}$ & $\mathbf{X}$ & $\mathbf{\%}$ & Sonuç \\
\hline Tümleştirme & 241 & 944,67 & 3,92 & 0,24 & Çoğunlukla \\
Kaçınma & 241 & 673,00 & 2,79 & 0,17 & Az \\
Ödün verme & 241 & 822,00 & 3,41 & 0,21 & Ara sıra-çoğunlukla \\
Uzlaşma & 241 & 939,20 & 3,90 & 0,23 & Çoğunlukla \\
Hükmetme & 241 & 606,00 & 2,51 & 0,15 & Hiçbir zaman-az \\
Toplam & 241 & 3984,87 & & & \\
\hline
\end{tabular}

Tablo 2'de okul yöneticilerinin çatışma yönetim sitillerini kullanma düzeyleri incelendiğinde $\% 24$ tümleştirme, \%17'sinin kaçınma, \%21'inin ödün verme, \%23 uzlaşma ve \%15'inin hükmetme sitilini kullandığ1 ortaya çıkmıştır. Çatışma yönetim sitillerinde "çoğunlukla " tümleştirme ve kaçınma stilini “az", ödün verme stilini, "ara sıra ve çoğunlukla”, hükmetme stilini "hiçbir zaman ve az” uygulandığ1 bulgusu edinilmiştir.

\section{Okul Yöneticilerine İlişkin Değişkenler İle Çatışma Yönetimi Arasındaki İlişki}

Bu bölümde okul yöneticilerinin çatışma yönetim stilleri cinsiyet, branş, yaş, meslekte geçen süre, yönetici olarak meslekte geçen süre, çalışan destek personeli sayısı gibi çeşitli değişkenler ile analiz edilmiştir.

\section{Cinsiyet ve Çatışma Yönetimi}

Çatışma yönetim stilleri alt boyutları ile cinsiyet arasında anlamlı bir ilişki olup olmadığının belirlenmesi amacıyla T-testi testi ile analiz edilmiştir. 
Tablo 3. Catısma Yönetim Stillerinin Cinsiyete Göre Dağzlım ve Betimsel İstatistikleri

\begin{tabular}{|c|c|c|c|c|}
\hline & Cinsiyet & $\mathbf{N}$ & $\mathbf{X}$ & Ss. \\
\hline \multirow{2}{*}{ Tümleştirme } & Kadın & 48 & 3.8681 & 0.53369 \\
\hline & Erkek & 193 & 3.9326 & 0.48090 \\
\hline \multirow{2}{*}{ Kaçınma } & Kadın & 48 & 2.7917 & 0.43962 \\
\hline & Erkek & 193 & 2.7927 & 0.45668 \\
\hline \multirow{2}{*}{ Ödün verme } & Kadın & 48 & 3.3333 & 0.52169 \\
\hline & Erkek & 193 & 3.4301 & 0.51123 \\
\hline \multirow{2}{*}{ Uzlaşma } & Kadın & 48 & 3.8583 & 0.43262 \\
\hline & Erkek & 193 & 3.9067 & 0.46008 \\
\hline \multirow{2}{*}{ Hükmetme } & Kadın & 48 & 2.5781 & 0.68835 \\
\hline & Erkek & 193 & 2.4987 & 0.49575 \\
\hline
\end{tabular}

Tablo 3’te okul yöneticilerinin kullanmış olduğu çatışma yönetim stilleri cinsiyeti değişkenine göre anlamlı bir farklılık gösterip göstermediğini belirlemek amacıyla gerçekleştirilen bağımsız grup t-testi sonucunda, grupların aritmetik ortalamaları arasındaki fark istatistiksel olarak anlamlı bulunmamıştır $(\mathrm{t}=0.704 ; \mathrm{p}>0.05)$.

\section{Yaş ve Çatışma Yönetimi}

Çatışma yönetim stilleri alt boyutları ile yaş grupları arasında anlamlı bir ilişki olup olmadığının belirlenmesi amacıyla tek yönlü ANOVA testi ile analiz edilmiştir.

Tablo 4. Catışma Yönetim Stilleri Yaş Gruplarna Göre Betimsel İstatistikler ve ANOVA Testi Sonuçlar

\begin{tabular}{|c|c|c|c|c|c|c|c|c|c|c|}
\hline & \multicolumn{2}{|c|}{ Tümleştirme } & \multicolumn{2}{|c|}{ Kaçınma } & \multicolumn{2}{|c|}{ Ödün verme } & \multicolumn{2}{|c|}{ Uzlaşma } & \multicolumn{2}{|c|}{ Hükmetme } \\
\hline & $\mathrm{n}$ & $\mathrm{X}$ & $\mathrm{n}$ & $x$ & $\mathrm{n}$ & $\mathrm{X}$ & $\mathrm{n}$ & $X$ & $\mathrm{n}$ & $X$ \\
\hline 25-35 yaş & 64 & 3.87 & 64 & 2.82 & 64 & 3.38 & 64 & 3.88 & 64 & 2.52 \\
\hline $36-40$ yaș & 120 & 3.93 & 120 & 2.81 & 120 & 3.38 & 120 & 3.89 & 120 & 2.52 \\
\hline $41-50$ yaş & 30 & 3.97 & 30 & 2.65 & 30 & 3.63 & 30 & 3.97 & 30 & 2.53 \\
\hline 51 ve üstü yaș & 27 & 3.93 & 27 & 2.82 & 27 & 3.40 & 27 & 3.89 & 27 & 2.46 \\
\hline Toplam & 241 & 3.92 & 241 & 2.79 & 241 & 3.41 & 241 & 3.90 & 241 & 2.51 \\
\hline $\mathrm{F}$ & 0.339 & & 1.145 & & - & & 0.27 & & 0.09 & \\
\hline Sig. & 0,797 & & 0.332 & & - & & 0.84 & & 0.96 & \\
\hline $\begin{array}{l}\text { Varyansların } \\
\text { homojenliği (FL- }\end{array}$ & $1.29-0.278$ & & $1.42-$ & & 5.20 & & 0.93 & & 1.50 & \\
\hline
\end{tabular}

Tablo 4’te çatışma yönetim stilleri ile yaş arasında anlamlı bir ilişki olup olmadığının belirlenmesi amacıyla ANOVA testinin yapılması için öncelikle Levene’s testi ile grup dağılımlarının varyanslarının homojen olup olmadığı hipotezi sınanmış, varyansların homojen olduğu saptanmıştır. Kaçınma stilini kullanma ile yaş arasında anlamlı bir ilişki olup olmadı̆̆ının belirlenmesi için $\mathrm{F}=01.14$ ve sig. $=0.33$ değerleri incelendiğinde sig. $>0.05$ olduğu için anlamlı bir farklılık olmadığı bulgusu ortaya çıkmıştır. Ödün verme stilini kullanma ile yaş grupları ortalamaları incelendiğinde genel olarak "ara sıra" ve "çoğunlukla" kaçınma stilini kullanma sınırında yer aldığı ifade edilebilir.

Ödün verme stilini kullanma ile yaş arasında anlamlı bir ilişki olup olmadı̆̆ının belirlenmesi için $\mathrm{F}=2.02$ ve sig. $=0.11$ değerleri incelendiğinde sig. $>0.05$ olduğu için anlamlı bir farklılık olmadığ1 bulgusu ortaya çıkmıştır. ANOVA testinin yapılması için öncelikle Levene’s testi ile grup dağılımlarının varyanslarının homojen olup olmadı̆̆1 hipotezi sınanmış, varyansların homojen olmadı̆̆1 saptanmıştır $(\mathrm{FL}=5.20$-Ssig.=0.002). Bu nedenle post hoc menüsünden heterojen varyanslı dağılımlarda kullanılan post hoc tekniklerden Tamhane's T2 tekniği seçilmiş ancak sig. $<0.05$ 'ten küçük olduğu için ödün verme stili ile yaş arasında anlamlı bir ilişki olduğu ortaya çıkmamıştır. Uzlaşma stilini kullanma ile yaş arasında anlamlı bir ilişki olup olmadığının belirlenmesi için $\mathrm{F}=0.27$ ve sig. $=0.84$ değerleri incelendiğinde sig. $>0.05$ olduğu için anlamlı bir farklılık olmadığı bulgusu ortaya çıkmıştır. Anova testi yapılmış hükmetme stilini kullanma ile yaş arasında anlamlı bir ilişki olup olmadığının belirlenmesi için $\mathrm{F}=0.09$ ve sig. $=0.96$ değerleri incelendiğinde sig. $>0.05$ olduğu için anlamlı bir farklılık olmadığı bulgusu ortaya çıkmıştır.

\section{Branş ve Çatışma Yönetimi}

Çatışma yönetim stilleri alt boyutları ile branşlar arasında anlamlı bir ilişki olup olmadığının belirlenmesi amacıyla tek yönlü ANOVA testi ile analiz edilmiştir. 
Tablo 5. Catışma Yönetim Stilleri Branşlara Göre ANOV A Testi Sonuclar

\begin{tabular}{|c|c|c|c|c|c|c|c|c|c|c|}
\hline & \multicolumn{2}{|c|}{ Tümleştirme } & \multicolumn{2}{|c|}{ Kaçınma } & \multicolumn{2}{|c|}{ Ödün verme } & \multicolumn{2}{|c|}{ Uzlaşma } & \multicolumn{2}{|c|}{ Hükmetme } \\
\hline & $\mathbf{n}$ & $\mathrm{X}$ & $\mathrm{n}$ & $\mathrm{X}$ & $\mathrm{n}$ & $\mathbf{X}$ & $\mathrm{n}$ & $\mathbf{X}$ & $\mathbf{n}$ & $\mathbf{X}$ \\
\hline Sınıf öğretmeni & 103 & 3.87 & 103 & 2.86 & 103 & 3.40 & 103 & 3.87 & 103 & 2.57 \\
\hline Fen bilgisi öğretmeni & 34 & 3.94 & 34 & 2.73 & 34 & 3.47 & 34 & 3.93 & 34 & 2.50 \\
\hline Sosyal bilgiler öğretmeni & 34 & 4.00 & 34 & 2.91 & 34 & 3.46 & 34 & 3.88 & 34 & 2.48 \\
\hline Türkçe öğretmeni & 19 & 4.00 & 19 & 2.75 & 19 & 3.42 & 19 & 3.88 & 19 & 2.42 \\
\hline Matematik öğretmeni & 9 & 3.78 & 9 & 2.78 & 9 & 3.44 & 9 & 3.89 & 9 & 2.50 \\
\hline $\begin{array}{l}\text { Din kültürü ve ahlak } \\
\text { bilgisi öğretmeni }\end{array}$ & 15 & 3.92 & 15 & 2.70 & 15 & 3.28 & 15 & 3.89 & 15 & 2.45 \\
\hline $\begin{array}{l}\text { Resim/iş teknik } \\
\text { öğretmeni }\end{array}$ & 6 & 4.11 & 6 & 2.72 & 6 & 3.50 & 6 & 4.23 & 6 & 2.46 \\
\hline $\begin{array}{l}\text { Diğer (okul öncesi, } \\
\text { rehber, İngilizce } \\
\text { öğretmeni vs.) }\end{array}$ & 21 & 3.94 & 21 & 2.54 & 21 & 3.36 & 21 & 3.95 & 21 & 2.49 \\
\hline Toplam & 241 & 3.92 & 241 & 2.79 & 241 & 3.41 & 241 & 3.90 & 241 & 2.51 \\
\hline $\mathrm{F}$ & 0.617 & & 1.827 & & 0.307 & & 0.613 & & 0.294 & \\
\hline Sig. & 0.742 & & 0.083 & & 0.950 & & 0.745 & & 0.956 & \\
\hline $\begin{array}{l}\text { Varyansların homojenliği } \\
\text { (FL-sig.) }\end{array}$ & $0.584-$ & & $1.70-($ & & $1.73-0$ & & $1.03-0$ & & $\begin{array}{l}1.44- \\
0.190\end{array}$ & \\
\hline
\end{tabular}

Tablo 5'te çatışma yönetim stilleri ile branş arasında anlamlı bir ilişki olup olmadığının belirlenmesi amacıyla ANOVA testinin yapılması için öncelikle Levene's testi ile grup dağılımlarının varyanslarının homojen olup olmadığı hipotezi sınanmış, varyansların homojen olduğu saptanmıştır (sig. $>0.05$ ). Tümleştime stilini kullanma ile branşlar arasında anlamlı bir ilişki olup olmadığının belirlenmesi için $\mathrm{F}=0.339$ ve sig. $=0.79$ değerleri incelendiğinde sig. $>0.05$ olduğu için anlamlı bir farkllık olmadığ bulgusu ortaya çımıştır.

Kaçınma stilini sınıf ve fen bilgisi öğretmenleri diğer branşlarda yer alan öğretmenlere göre kaçınma stilini daha çok kullandığı ifade edilebilir. Kaçınma stilini kullanma ile branş arasında anlamlı bir ilişki olup olmadığının belirlenmesi için $\mathrm{F}=1.82$ ve sig. $=0.08$ değerleri incelendiğinde sig. $>0.05$ olduğu için anlamlı bir farklılık olmadığı bulgusu ortaya çıkmıştır. Ödün verme stilini kullanmada din kültürü ve ahlak bilgisi öğretmeni branşında yer alan okul yöneticilerinin diğer branşlarda yer alan okul yöneticilerine göre daha az ödün verme stilini kullandığı ifade edilebilir. Ödün verme stilini kullanma ile branş arasında anlamlı bir ilişki olup olmadığının belirlenmesi için $\mathrm{F}=0.30$ ve sig. $=0.95$ değerleri incelendiğinde sig. $>0.05$ olduğu için anlamlı bir farklılık olmadığı bulgusu ortaya çıkmıştır. Uzlaşma stilini kullanma ile Resim öğretmenliği branşında yer alan okul yöneticilerinin uzlaşma stilini "her zaman" kullandıkları bulgusu edinilmiştir. Uzlaşma stilini kullanma ile branş arasında anlamlı bir ilişki olup olmadığının belirlenmesi için $\mathrm{F}=0.61$ ve sig. $=0.74$ değerleri incelendiğinde sig. $>0.05$ olduğu için anlamlı bir farkll11k olmadığı bulgusu ortaya çıkmıştır. Hükmetme stilini kullanma ile branş arasında anlamlı bir ilişki olup olmadığının belirlenmesi için $\mathrm{F}=0.29$ ve sig. $=0.85$ değerleri incelendiğinde sig. $>0.05$ olduğu için anlamlı bir farklılık olmadığ bulgusu ortaya çıkmıştır.

\section{Meslekte Geçen Süre ve Çatışma Yönetimi}

Çatışma yönetim stilleri alt boyutları ile meslekte geçen süre arasında anlamlı bir ilişki olup olmadığının belirlenmesi amacıyla tek yönlü ANOVA testi ile analiz edilmiştir.

Tablo 6. Çatışma Yönetim Stilleri Meslekte Geçen Sürelere Göre ANOV A Testi Sonuçlar

\begin{tabular}{|c|c|c|c|c|c|c|c|c|c|c|}
\hline & \multicolumn{2}{|c|}{ Tümleştirme } & \multicolumn{2}{|c|}{ Kaçınma } & \multicolumn{2}{|c|}{ Ödün verme } & \multicolumn{2}{|c|}{ Uzlaşma } & \multicolumn{2}{|c|}{ Hükmetme } \\
\hline & $\mathrm{n}$ & $\mathrm{X}$ & $\mathrm{n}$ & $\mathrm{X}$ & $\mathrm{n}$ & $\mathrm{X}$ & $\mathrm{n}$ & $\mathrm{X}$ & $\mathrm{n}$ & $\mathrm{X}$ \\
\hline $1-5 \mathrm{yll}$ & 12 & 3.88 & 12 & 2.86 & 12 & 3.40 & 12 & 3.88 & 12 & 2.35 \\
\hline $6-10$ y1l & 34 & 3.99 & 34 & 2.82 & 34 & 3.45 & 34 & 3.98 & 34 & 2.43 \\
\hline $11-15$ yll & 90 & 3.88 & 90 & 2.79 & 90 & 3.36 & 90 & 3.86 & 90 & 2.60 \\
\hline $16-20 \mathrm{yll}$ & 78 & 3.95 & 78 & 2.79 & 78 & 3.43 & 78 & 3.95 & 78 & 2.50 \\
\hline 21 yll ve üstü & 27 & 3.89 & 27 & 2.74 & 27 & 3.49 & 27 & 3.76 & 27 & 2.46 \\
\hline Toplam & 241 & 3.92 & 241 & 2.79 & 241 & 3.41 & 241 & 3.90 & 241 & 2.51 \\
\hline F & \multicolumn{2}{|c|}{0.461} & \multicolumn{2}{|c|}{0.196} & \multicolumn{2}{|c|}{0.436} & \multicolumn{2}{|c|}{1.372} & \multicolumn{2}{|c|}{1.144} \\
\hline Sig. & \multicolumn{2}{|c|}{0.764} & \multicolumn{2}{|c|}{0.940} & \multicolumn{2}{|c|}{0.783} & \multicolumn{2}{|c|}{0.244} & \multicolumn{2}{|c|}{0.336} \\
\hline $\begin{array}{l}\text { Varyansların homojenliği } \\
\text { (FL-sig.) }\end{array}$ & \multicolumn{2}{|c|}{$0.780-0.539$} & \multicolumn{2}{|c|}{$0.997-0.410$} & \multicolumn{2}{|c|}{$0.977-0.421$} & \multicolumn{2}{|c|}{$0.952-0.435$} & \multicolumn{2}{|c|}{$0.634-0.639$} \\
\hline
\end{tabular}


Tablo 6'da çatışma yönetim stilleri ile meslekte geçen süreler arasında anlamlı bir ilişki olup olmadığının belirlenmesi amacıyla ANOVA testinin yapılması için öncelikle Levene's testi ile grup dağılımlarının varyanslarının homojen olup olmadığ1 hipotezi sınanmış, varyansların homojen olduğu saptanmıştır (sig.>0.05). Tablo değerleri incelendiğinde sig. $>0.05$ olduğu için anlamlı bir farklılık olmadiğı bulgusu ortaya çıkmıştır.

\section{Meslekte Yönetici Olarak Geçirilen Süre ve Çatışma Yönetimi}

Çatışma yönetim stilleri alt boyutları ile meslekte yönetici olarak geçen süre arasında anlamlı bir ilişki olup olmadığının belirlenmesi amacıyla tek yönlü ANOVA testi ile analiz edilmiş, post-hoc analiz tekniği ile ortaya çıkan farklılıkları belirlemek için Tukey testi yapılmıştır.

Tablo 7. Catışma Yönetim Stilleri Meslekte Yönetici Olarak Geçirilen Sürelere Göre ANOV A Testi Sonuçlar

\begin{tabular}{|c|c|c|c|c|c|c|c|c|c|c|}
\hline & \multicolumn{2}{|c|}{ Tümleştirme } & \multicolumn{2}{|c|}{ Kaçınma } & \multicolumn{2}{|c|}{ Ödün verme } & \multicolumn{2}{|c|}{ Uzlaşma } & \multicolumn{2}{|c|}{ Hükmetme } \\
\hline & $\mathrm{n}$ & $\mathbf{X}$ & $\mathbf{n}$ & $\mathbf{X}$ & $\mathrm{n}$ & $\mathbf{X}$ & $\mathbf{n}$ & $\mathrm{X}$ & $\mathbf{n}$ & $\mathbf{X}$ \\
\hline $1-5 \mathrm{yll}$ & 86 & 3.90 & 86 & 2.78 & 86 & 3.39 & 86 & 3.83 & 86 & 2.51 \\
\hline $6-10 \mathrm{yll}$ & 107 & 3.94 & 107 & 2.82 & 107 & 3.43 & 107 & 3.99 & 107 & 2.54 \\
\hline $11-15 \mathrm{yll}$ & 21 & 3.98 & 21 & 2.87 & 21 & 3.57 & 21 & 3.88 & 21 & 2.45 \\
\hline $16-20 \mathrm{y} 1 \mathrm{l}$ & 27 & 3.85 & 27 & 2.68 & 27 & 3.26 & 27 & 3.78 & 27 & 2.47 \\
\hline $21 \mathrm{yll}$ ve üstü & 241 & 3.92 & 241 & 2.79 & 241 & 3.41 & 241 & 3.90 & 241 & 2.51 \\
\hline Toplam & 86 & 3.90 & 86 & 2.78 & 86 & 3.39 & 86 & 3.83 & 86 & 2.51 \\
\hline $\mathrm{F}$ & 0.39 & & 0.91 & & 1.57 & & 2.75 & & 0.24 & \\
\hline Sig. & 0.75 & & 0.43 & & 0.19 & & 0.04 & & 0.86 & \\
\hline $\begin{array}{l}\text { Varyansların homojenliği } \\
\text { (FL-sig.) }\end{array}$ & $\begin{array}{l}1.42 \\
-0.236 \\
\end{array}$ & & $\begin{array}{l}2.50- \\
0.060 \\
\end{array}$ & & $\begin{array}{l}2.35- \\
0.072 \\
\end{array}$ & & 0.14 & 936 & 0.63 & \\
\hline
\end{tabular}

Tablo 7'de çatışma yönetim stilleri ile meslekte yönetici olarak geçen süreler arasında anlamlı bir ilişki olup olmadı̆̆ının belirlenmesi amacıyla ANOVA testi sonucunda tabloda görüldüğü gibi anlamlı bulunmamıştır. Ancak uzlaşma stili aritmetik ortalamalarının gelir değişkenine göre anlamlı bir farklılık gösterip göstermediğini belirlemek amacıyla yapılan tek yönlü varyans analizi (ANOVA) sonucunda ögretici olarak meslekte geçen süre gruplarının aritmetik ortalamaları arasındaki fark istatistiksel olarak anlamlı bulunmuştur $(\mathrm{F}=2.75-0.04)$. Bu işlemin ardından ANOVA sonrası belirlenen anlamlı farklılı̆̆ın hangi gruplardan kaynaklandığını belirlemek üzere tamamlayıcı post-hoc analiz tekniklerine geçilmiştir. ANOVA sonrası hangi post-hoc çoklu karşılaştırma tekniğinin kullanılacağına karar vermek için öncelikle Levene's testi ile grup dağılımlarının varyanslarının homojen olup olmadığı hipotezi sınanmış, varyansların homojen olduğu saptanmış $(\mathrm{LF}=0.141-0.04)$ ve anlamlı bir fark olup olmadı̆̆ koşulları sağlamadığ1 için sınanmamıştır. Bunun üzerine varyansların homojen olması durumunda yaygınlıkla kullanılan Tukey çoklu karşılaştırma tekniği tercih edilmiştir. Tukey testinin tercih edilmesinin nedeni testin alpha tipi hataya karş1 duyarlı olmasıdır. Gerçekleştirilen Tukey çoklu karşılaştırma analizi sonuçları aşağıda sunulmuştur.

Tablo 8. Çatıs̆ma Yönetim Stilleri Meslekte Geçirilen Süre İki Ortalama Arasındaki Farken Anlamlılı Testi İcin Tukey Testi Sonuçlar

\begin{tabular}{|c|c|c|c|c|}
\hline $\begin{array}{l}\text { (I) eğitim yöneticisi } \\
\text { olarak hizmet yılı }\end{array}$ & $\begin{array}{l}\text { (J) eğitim yöneticisi } \\
\text { olarak hizmet yılı }\end{array}$ & X farkı (I-J) & Std. hata & Sig. \\
\hline \multirow{3}{*}{$1-5 \mathrm{yll}$} & $6-10 \mathrm{yll}$ & -.15901 & .06508 & .042 \\
\hline & $16-20 \mathrm{y} 1 \mathrm{l}$ & -.04828 & .10938 & .971 \\
\hline & $11-15$ y1l & .05013 & .09913 & .958 \\
\hline \multirow{3}{*}{$6-10 \mathrm{y} 1 \mathrm{l}$} & $1-5 \mathrm{y} 1 \mathrm{l}$ & .15901 & .06508 & .042 \\
\hline & $16-20 \mathrm{y} 1 \mathrm{l}$ & .11073 & .10725 & .731 \\
\hline & $11-15$ y1l & .20914 & .09678 & .137 \\
\hline \multirow{3}{*}{$16-20 \mathrm{yll}$} & $1-5 \mathrm{y} 1 \mathrm{l}$ & .04828 & .10938 & .971 \\
\hline & $6-10 \mathrm{yll}$ & -.11073 & .10725 & .731 \\
\hline & $11-15 \mathrm{y} 1 \mathrm{l}$ & .09841 & .13075 & .875 \\
\hline \multirow{3}{*}{$11-15 \mathrm{yll}$} & $1-5 \mathrm{y} 1 \mathrm{l}$ & -.05013 & .09913 & .958 \\
\hline & $6-10 \mathrm{yll}$ & -.20914 & .09678 & .137 \\
\hline & $16-20 \mathrm{y} 1 \mathrm{l}$ & -.09841 & .13075 & .875 \\
\hline
\end{tabular}


Tablo 8'de uzlaşma stili, meslekte yönetici olarak geçirilen süre değişkenine göre hangi alt gruplar arasında farklılaştığını belirlemek üzere yapılan tek yönlü varyans analizi (ANOVA) sonrası (sig.<0.05) düzeyinde anlamlı bir farklılık saptanmışır. Bu durum, 6-10 yıl okul yöneticisi olarak çalışanların 1-5 yıl okul yöneticisi olarak çalışanlara göre daha fazla uzlaşma kullandıklarını ortaya koymaktadır. Diğger alt boyutlar arasındaki farkllık istatistiksel olarak anlamlı bulunmamıştır ( $\mathrm{p}>0.05)$.

\section{Okuldaki Destek Personeli ve Çatışma Yönetimi}

Çatışma yönetim stilleri alt boyutları okuldaki destek personeli grupları arasında anlamlı bir ilişki olup olmadığının belirlenmesi amacıyla tek yönlü ANOVA testi ile analiz edilmiştir.

Tablo 9. Catısma Yönetim Stilleri Okuldaki Destek Personeli Saynlarna Göre Betimsel İstatistikler ve ANOVA Testi Sonuclar

\begin{tabular}{|c|c|c|c|c|c|c|c|c|c|c|}
\hline & \multicolumn{2}{|c|}{ Tümleştirme } & \multicolumn{2}{|c|}{ Kaçınma } & \multicolumn{2}{|c|}{ Ödün verme } & \multicolumn{2}{|c|}{ Uzlaşma } & \multicolumn{2}{|c|}{ Hükmetme } \\
\hline & $\mathbf{n}$ & $\mathrm{X}$ & $\mathbf{n}$ & $\mathbf{X}$ & $\mathrm{n}$ & $\mathbf{X}$ & $\mathrm{n}$ & $\mathbf{X}$ & $\mathrm{n}$ & $\mathbf{X}$ \\
\hline 15-35 kişi & 150 & 3.94 & 150 & 2.81 & 150 & 3.40 & 150 & 3.90 & 150 & 2.50 \\
\hline 36-50 kişi & 55 & 3.92 & 55 & 2.79 & 55 & 3.45 & 55 & 3.91 & 55 & 2.46 \\
\hline 51 ve üstü kişi & 36 & 3.83 & 36 & 2.74 & 36 & 3.41 & 36 & 3.84 & 36 & 2.65 \\
\hline Toplam & 241 & 3.92 & 241 & 2.79 & 241 & 3.41 & 241 & 3.90 & 241 & 2.51 \\
\hline $\mathrm{F}$ & \multicolumn{2}{|c|}{0.758} & \multicolumn{2}{|c|}{0.297} & \multicolumn{2}{|c|}{0.216} & \multicolumn{2}{|c|}{0.290} & \multicolumn{2}{|c|}{1.490} \\
\hline Sig. & \multicolumn{2}{|c|}{0.470} & \multicolumn{2}{|c|}{0.744} & \multicolumn{2}{|c|}{0.806} & \multicolumn{2}{|c|}{0.749} & \multicolumn{2}{|c|}{0.227} \\
\hline $\begin{array}{l}\text { Varyansların } \\
\text { homojenliği (FL-sig.) }\end{array}$ & \multicolumn{2}{|c|}{$2.26-0.106$} & \multicolumn{2}{|c|}{$1.38-0.252$} & \multicolumn{2}{|c|}{$1.24-0.290$} & \multicolumn{2}{|c|}{$0.418-0.65$} & \multicolumn{2}{|c|}{$1.33-0.266$} \\
\hline
\end{tabular}

Tablo 9'da görülebileceği üzere çatışma yönetimi ölçeği alt faktörlerinin okuldaki destek personeli sayısı değişkenine göre anlamlı bir farklılık gösterip göstermediğini belirlemek amacıyla yapılan tek yönlü varyans analizi (ANOVA) sonucunda okuldaki destek personelinin sayılarına ilişkin gruplarının aritmetik ortalamaları arasındaki fark istatistiksel olarak anlamlı bulunmamıştır.

\section{Okul Yöneticilerin Benlik Saygısına İlişkin Bulgular}

Bu bölümde okul benlik sayg1sı ölçeği puanları; cinsiyet, branş, yaş, meslekte geçen süre, yönetici olarak meslekte geçen süre, çalışan destek personeli sayıs1, hizmet içi eğitime katılma gibi çeşitli değişkenler ile analiz edilmiştir.

Araştırma sonuçlarına göre genel olarak benlik saygisı ile ilgili olumlu ve olumsuz sorular değerlendirildiğinde verilen cevapların benlik saygısının yüksek olduğuna ilişkin bulgulanı ön plana çıktı̆̆1 görülmektedir. Benlik saygısı ile ilgili olumlu maddelerinin ortalamaları incelendiğinde 2.23 olduğu bulgusu edinilmiştir. Buna göre okul yöneticilerinin olumlu benlik saygisı ile ilgili sorulara olumlu yanıt verdikleri ve bu durum ise okul yöneticilerinin yüksek benlik saygısına sahip olduklarını kanıtlar niteliktedir.

Benlik saygısı ortalamaları hesaplandıktan sonra bu ortalamalar sayı doğrusu üzerine yerleştirilmiştir. Sayı doğrusunda sağdan sola 5 en düşük benlik saygısını, 1 ise en yüksek benlik saygısını ifade edecek şekilde yerleştirilmiştir. Buna göre olumlu benlik saygısı ile ilgili sorulara verilen yanıtların ortalamaları X. 2,23 olarak hesaplanmış olup okul yöneticilerinin yüksek benlik saygısına sahip oldukları ifade edilebilir.

\section{Okul Yöneticilerine İlişkin Değişkenler İle Benlik Saygısı Arasındaki İlişki}

Benlik saygisı ölçeği 32 sorudan oluşmakta olup verilen cevaplar 1 ile 5 arasında değişen değerlere göre ölçek puanları hesaplanmıştır. Buna göre 32 sorudan oluşan ölçek alt sınırı 32 ve üst sınırı 160 olarak belirlenmiştir. Çok yüksek benlik saygisı 160-32=128 olarak belirlenmiş olup çıkan bu sonuç 100'e eşitlenmiştir (128=100 puan). Araştırmada gerçekleşen ölçek ortalama puan ise 126,39'dur. Buna göre $((126,39-32) / 128=0.74)$ gerçekleşen benlik saygısı \%74 olarak hesaplanmıştır. Çıkan bu sonuçlar incelendiğinde yüksek bir benlik saygısının olduğu ifade edilebilir.

\section{Cinsiyet ve Benlik Saygısı}

Benlik saygısı ölçek puanları ile cinsiyet grupları arasında anlamlı bir ilişki olup olmadığının belirlenmesi amacıyla t-testi yapılmıştır. 
Tablo 10. Benlik Saygısı Ölçeği Puanları Cinsiyet Gruplarna Göre Betimsel İstatistikeler

\begin{tabular}{llcccc}
\hline & Cinsiyet & N & X & Ss. & Std. hata X \\
\hline Benlik saygısı ölçeği & Kadın & 48 & 124.7 & 17.9 & 2.6 \\
& Erkek & 193 & 126.8 & 18.1 & 1.3 \\
\hline
\end{tabular}

Tablo 10'da benlik saygısı ölçeği ortalamanın cinsiyeti değişkenine göre anlamlı bir farklılık gösterip göstermediğini belirlemek amacıyla gerçekleştirilen bağımsız grup t-testi yapılmıştır.

Tablo 11. Cinsiyet ve Benlik Saygzs t-testi

\begin{tabular}{lccccccc}
\hline & F & Sig & $\mathbf{t}$ & df & Sig. - tailed & X Fark1 & Std. Hata fark \\
\hline Varsayılan eşitlikler & .025 & .873 & -.740 & 239 & .460 & -2.15717 & 2.91413 \\
Eşit farklar varsayılmadı & & & -.746 & 72.894 & .458 & -2.15717 & 2.89134 \\
\hline
\end{tabular}

Tablo 11'de t-testi sonucunda, grupların aritmetik ortalamaları arasındaki fark istatistiksel olarak anlamlı bulunmamıştır ( $\mathrm{t}=0,689 ; \mathrm{p}>0,05)$.

\section{Branş ve Benlik Saygısı}

Benlik saygısı ölçek puanları, branşlar arasında anlamlı bir ilişki olup olmadı̆̆ının belirlenmesi amaciyla tek yönlü ANOVA testi ile analiz edilmiştir.

Tablo 12. Benlik Saygısı Ölçeği Puanlar Branş Gruplarna Göre Betimsel İstatistikler ve ANOV A Testi İstatistikleri

\begin{tabular}{|c|c|c|c|c|c|c|c|c|}
\hline & \multirow[t]{2}{*}{$\mathbf{N}$} & \multirow[t]{2}{*}{$\mathbf{X}$} & \multirow[t]{2}{*}{ Ss. } & \multirow{2}{*}{$\begin{array}{l}\text { Std. } \\
\text { hata }\end{array}$} & \multicolumn{2}{|c|}{ 95\% Güven aralı̆̆1 } & \multirow[t]{2}{*}{$\mathbf{F}$} & \multirow[t]{2}{*}{ sig. } \\
\hline & & & & & Alt sinır & Üst sinır & & \\
\hline Sınıf öğretmeni & 103 & 125.49 & 18.44 & 1.82 & 121.88 & 129.09 & 1.65 & 0.21 \\
\hline Fen bilgisi öğretmeni & 34 & 127.21 & 17.74 & 3.04 & 121.02 & 133.39 & & \\
\hline Sosyal bilgiler öğretmeni & 34 & 125.09 & 17.57 & 3.01 & 118.96 & 131.22 & & \\
\hline Türkçe öğretmeni & 19 & 127.84 & 21.76 & 4.99 & 117.35 & 138.33 & & \\
\hline Matematik öğretmeni & 9 & 128.78 & 15.92 & 5.31 & 116.54 & 141.01 & & \\
\hline $\begin{array}{l}\text { Din kültürü ve ahlak bilgisi } \\
\text { öğretmeni }\end{array}$ & 15 & 125.07 & 13.40 & 3.46 & 117.65 & 132.49 & & \\
\hline Resim/iş teknik öğretmeni & 6 & 140.50 & 10.15 & 4.15 & 129.84 & 151.16 & & \\
\hline $\begin{array}{l}\text { Diğer (okul öncesi. rehber. İngilizce } \\
\text { öğretmeni vs.) }\end{array}$ & 21 & 126.24 & 19.85 & 4.33 & 117.20 & 135.28 & & \\
\hline Toplam & 241 & 126.39 & 18.05 & 1.16 & 124.10 & 128.68 & & \\
\hline
\end{tabular}

Tablo 12'de ANOVA sonrası hangi post-hoc çoklu karşılaştırma tekniğinin kullanılacağına karar vermek için öncelikle Tablo 13'te görülebileceği üzere benlik saygısı ölçeği aritmetik ortalamanın yöneticilerinin branş değişkenine göre anlamlı bir farklılık gösterip göstermediğini belirlemek amacıyla yapılan tek yönlü varyans analizi (ANOVA) sonucunda okuldaki branş gruplarına ilişkin gruplarının aritmetik ortalamaları arasındaki fark istatistiksel olarak anlamlı bulunmamıştır $(\mathrm{F}=1.65-0.21)$.

\section{Yaş ve Benlik Saygısı}

Benlik saygısı ölçek puanları, yaş grupları arasında anlamlı bir ilişki olup olmadığının belirlenmesi amacıyla tek yönlü ANOVA testi ile analiz edilmiştir.

Tablo 13. Benlik Saygısı Ölçeği Puanlar Branş Gruplarna Göre Betimsel İstatistikler ve ANOVA Testi Istatistikleri

\begin{tabular}{|c|c|c|c|c|c|c|c|c|}
\hline & \multirow[t]{2}{*}{$\mathbf{N}$} & \multirow[t]{2}{*}{$\mathbf{X}$} & \multirow[t]{2}{*}{ Ss. } & \multirow{2}{*}{$\begin{array}{l}\text { Std. } \\
\text { hata }\end{array}$} & \multicolumn{2}{|c|}{ 95\% Güven aralığ1 } & \multirow[t]{2}{*}{$\mathbf{F}$} & \multirow[t]{2}{*}{ sig. } \\
\hline & & & & & Alt sinir & Üst sinır & & \\
\hline Sınıf öğretmeni & 103 & 125.49 & 18.44 & 1.82 & 121.88 & 129.09 & 1.65 & 0.21 \\
\hline Fen bilgisi öğretmeni & 34 & 127.21 & 17.74 & 3.04 & 121.02 & 133.39 & & \\
\hline Sosyal bilgiler öğretmeni & 34 & 125.09 & 17.57 & 3.01 & 118.96 & 131.22 & & \\
\hline Türkçe öğretmeni & 19 & 127.84 & 21.76 & 4.99 & 117.35 & 138.33 & & \\
\hline Matematik öğretmeni & 9 & 128.78 & 15.92 & 5.31 & 116.54 & 141.01 & & \\
\hline $\begin{array}{l}\text { Din kültürü ve ahlak bilgisi } \\
\text { öğretmeni }\end{array}$ & 15 & 125.07 & 13.40 & 3.46 & 117.65 & 132.49 & & \\
\hline Resim/iș teknik öğretmeni & 6 & 140.50 & 10.15 & 4.15 & 129.84 & 151.16 & & \\
\hline $\begin{array}{l}\text { Diğer (okul öncesi. rehber. İngilizce } \\
\text { ögrretmeni vs.) }\end{array}$ & 21 & 126.24 & 19.85 & 4.33 & 117.20 & 135.28 & & \\
\hline Toplam & 241 & 126.39 & 18.05 & 1.16 & 124.10 & 128.68 & & \\
\hline
\end{tabular}


ANOVA sonrası hangi post-hoc çoklu karşılaştırma tekniğinin kullanılacağına karar vermek için öncelikle Levene's testi ile grup dağılımlarının varyanslarının homojen olup olmadığı hipotezi sınanmış, varyansların homojen olduğu saptanmıştır ( $(\mathrm{LF}=1.65-0.12)$. Tablo-13’te görülebileceği üzere benlik saygısı ölçeği aritmetik ortalamanın yöneticilerinin branş değişkenine göre anlamlı bir farklılık gösterip göstermediğini belirlemek amaciyla yapılan tek yönlü varyans analizi (ANOVA) sonucunda okuldaki branş gruplarına ilişkin gruplarının aritmetik ortalamaları arasındaki fark istatistiksel olarak anlamlı bulunmamıştır $(\mathrm{F}=1.65-0.21)$.

\section{Yaş ve Benlik Saygısı}

Benlik saygısı ölçek puanları, yaş grupları arasında anlamlı bir ilişki olup olmadığının belirlenmesi amacıyla tek yönlü Anova testi ile analiz edilmiștir.

Tablo 14. Benlike Saygısı Ölçeği Puanlar Yas Gruplarna Göre Betimsel İstatistikler ve ANOVA Testi İstatistikleri

\begin{tabular}{|c|c|c|c|c|c|c|c|c|}
\hline & \multirow[t]{2}{*}{$\mathbf{N}$} & \multirow[t]{2}{*}{$\mathbf{X}$} & \multirow[t]{2}{*}{ Ss. } & \multirow[t]{2}{*}{ Std. hata } & \multicolumn{2}{|c|}{ 95\% Güven aralığ1 } & \multirow[t]{2}{*}{$\mathbf{F}$} & \multirow[t]{2}{*}{ sig. } \\
\hline & & & & & Alt sinir & Üst sinur & & \\
\hline 25-35 yaş & 64 & 125.00 & 16.20 & 2.02 & 120.95 & 129.05 & 0.33 & 0.79 \\
\hline $36-40$ yaş & 120 & 126.99 & 19.01 & 1.74 & 123.56 & 130.43 & & \\
\hline 41-50 yaş & 30 & 128.30 & 19.02 & 3.47 & 121.20 & 135.40 & & \\
\hline 51 ve üstü & 27 & 124.93 & 17.38 & 3.35 & 118.05 & 131.80 & & \\
\hline Toplam & 241 & 126.39 & 18.05 & 1.16 & 124.10 & 128.68 & & \\
\hline
\end{tabular}

Yapılan analiz sonucunda benlik saygısı ölçeği ortalamalarının yaş değişkenine göre anlamlı bir farklılık gösterip göstermediğini belirlemek amacıyla yapılan tek yönlü varyans analizi (ANOVA) sonucunda yaş gruplarının aritmetik ortalamaları arasındaki fark istatistiksel olarak anlamlı bulunmamışıı $(\mathrm{F}=0.33-0.79)$.

\section{Meslekte Geçen Süre ve Benlik Saygısı}

Benlik saygısı ölçek puanları ile meslekte geçen süreler arasında anlamlı bir ilişki olup olmadığının belirlenmesi amacıyla tek yönlü Anova testi ile analiz edilmiştir.

Tablo 15. Benlik Saygısı Ölçeği Puanlar Meslekte Geçen Sürelere Göre Betimsel İstatistikler ve Anova Testi Istatistikleri

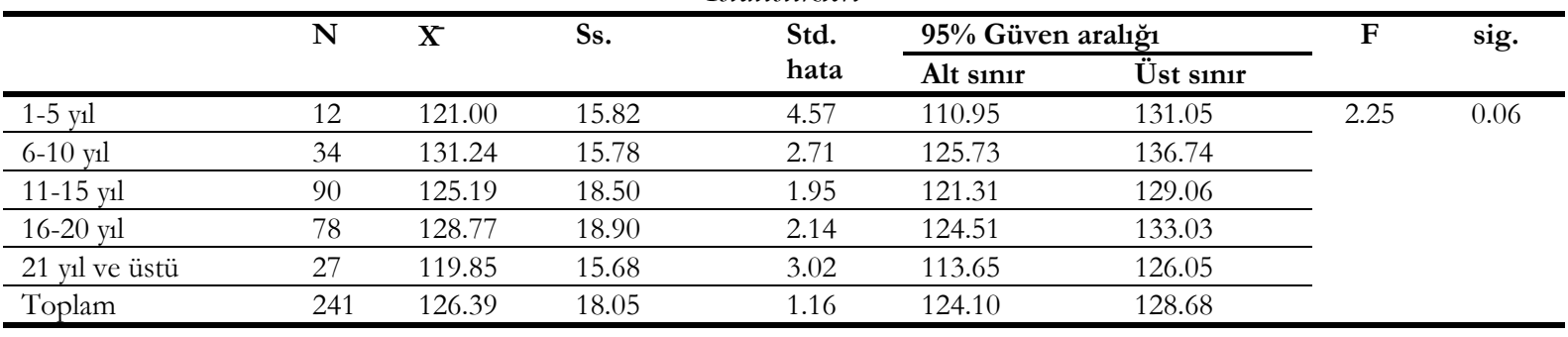

Yapılan tek yönlü varyans analizi (ANOVA) sonucunda meslekte geçen süre gruplarının aritmetik ortalamaları arasındaki fark istatistiksel olarak anlamlı bulunmamıştır ( $\mathrm{F}=2.25-0.06)$.

\section{Okuldaki Destek Personeli ve Benlik Sayg1sı}

Tablo 16. Benlik Saygısı Ölceği Puanlar Okuldaki Destek Personeli Saynlarna Göre Betimsel İstatistikler ve ANOVA Testi Istatistikleri

\begin{tabular}{|c|c|c|c|c|c|c|c|c|}
\hline & \multirow[t]{2}{*}{$\mathbf{N}$} & \multirow[t]{2}{*}{$\bar{X}$} & \multirow[t]{2}{*}{ Ss. } & \multirow{2}{*}{$\begin{array}{l}\text { Std. } \\
\text { hata }\end{array}$} & \multicolumn{2}{|c|}{$95 \%$ Güven aralığ1 } & \multirow[t]{2}{*}{$\mathbf{F}$} & \multirow[t]{2}{*}{ sig. } \\
\hline & & & & & Alt sinir & Üst sinır & & \\
\hline 15-35 kişi & $\overline{150}$ & 126.27 & 17.51 & 1.43 & 123.44 & 129.09 & 0.20 & 0.82 \\
\hline 36-50 kişi & 55 & 127.55 & 19.79 & 2.67 & 122.20 & 132.90 & & \\
\hline 51 ve üstü & 36 & 125.17 & 17.94 & 2.99 & 119.10 & 131.24 & & \\
\hline Toplam & 241 & 126.39 & 18.05 & 1.16 & 124.10 & 128.68 & & \\
\hline
\end{tabular}

Tablo 16'da Yapılan tek yönlü varyans analizinde "okuldaki destek personeli" değişkeni ile benlik saygısı ortalamaları arasında anlamlı bir farkın olup olmadığının belirlenmesi maçıyla tek yönlü (ANOVA) test yapılmış anlamlı bir farklılık göstermediği bulgusu edinilmiştir $(\mathrm{F}=0.20-0.82)$. 


\section{Çatışma Yönetim Stilleri İle Benlik Saygısı İlişkisi}

Tablo 17. Benlik Saygısı Ölçeği ve Çatıs̆ma Yönetim Stilleri Arasindaki Korelasyon Analizi

\begin{tabular}{|c|c|c|c|c|c|c|c|}
\hline & & $\begin{array}{c}\text { Çatışma Yönetimi } \\
\text { Stilleri }\end{array}$ & Tümleştirme & Kaçınma & Ödün verme & Uzlaşma & Hükmetme \\
\hline Benlik & Pearson Correlation & $.302^{* *}$ & .004 & $.381^{* *}$ & $.600^{* *}$ & -.097 & $.302^{* *}$ \\
\hline \multirow[t]{4}{*}{ Sayg1s1 } & Sig. (2-tailed) & .000 & .948 & .000 & .000 & .132 & .000 \\
\hline & $\begin{array}{l}\text { Sum of Squares and } \\
\text { Cross-products }\end{array}$ & 642.454 & 8.210 & 847.225 & 1181.376 & -227.380 & 642.454 \\
\hline & Covariance & 2.677 & .034 & 3.530 & 4.922 & -.947 & 2.677 \\
\hline & $\mathrm{N}$ & 241 & 241 & 241 & 241 & 241 & 241 \\
\hline
\end{tabular}

**Correlation is significant at the 0.01 level (2-tailed).

$*$ Correlation is significant at the 0.05 level (2-tailed).

Tablo 17'de Çatışma yönetim stillerini belirlemek amacıyla Pearson korelasyon analizi yapılmıştır. Pearson korelasyon analizi verilerin normal dağılması nedeniyle tercih edilmiş sig. (2-tailed) $<0.05$ 'ten küçük olduğu bulgusu edinilmiştir. Tablo incelendiğinde bazı önemli korelasyonlara dair şu yorumlar yapılabilir; benlik saygısı yüksek olan yöneticilerin kaçınma stilini kullanmakla beraber hükmetme stiline göre daha fazla tercih ettikleri yorumu yapılabilir. Kaçınma stili, geri çekilme, kaçma, sorunu görmeme, zamana bırakma gibi özellikler taşımaktadır. Benlik saygısı yükseldikçe kaçınma stilini kullanma oranı artmışır.

Benlik sayg1sı ile ödün verme stili arasında pozitif korelasyon olduğu bulgusu edinilmiştir. En güçlü ilişki Ödün verme stilinde farklılıkların ikinci plana itilerek, ortak yönlerin ön plana çıkarıldığı, karşı tarafın tatmin edilmeye çalışıldığı bir yol izlenmektedir. Bu kapsamda benlik sayg1sı yüksek olan bireylerin ödün verme stilini daha çok kullandıkları ifade edilebilir.

Benlik saygısı ile hükmetme stili arasında pozitif korelasyon olduğu bulgusu edinilmiştir. Pearson korelasyon analizi verilerin normal dağılması nedeniyle tercih edilmiş ve sig. (2-tailed) $<0.01$ 'den küçük olduğu bulgusu edinilmiştir. Hükmetme stilinde bireyler kendi amaçlarını gerçekleştirmek için başkalarının isteklerini, beklentilerini ve ihtiyaçlarını dikkate almaz, kendilerine yüksek ilgi gösterirken diğerlerine düşük düzeyde ilgi gösterirler. Benlik saygısı ile hükmetme stili arasındaki bu korelasyonun yüksek olmasının nedeni bireyin isteklerini, kendi düşüncelerini ön planda tutması beklentilerini yüksek olarak belirlemesi olarak yorumlanabilir.

\section{Sonuç Tartışma ve Öneriler}

Bu çalışmada okul yöneticilerinin çatışma yönetim stillerini hangi derecede kullandıkları algılamalarına ilişkin sonuçlar ile cinsiyet, yaş, öğretmenlik branşı, öğretmen olarak hizmet yıll, eğitim yöneticisi olarak hizmet yll, okuldaki destek personeli, benlik saygılarına göre analiz edilmiştir. Araştırmada elde edilen sonuçlar aşağıda sunulmuştur.

Okul yöneticileri çatışma yönetim stillerinden tümleştirme ve uzlaşma stilini "çoğunlukla", ödün verme "ara sıra", hükmetme ve kaçınma stilini ise "az" kullandıkları sonucu ortaya çıkmışır. Katılımcıların en çok tercih ettikleri çatışma yönetim stili tümleştirme, uzlaşma ve ödün verme olurken en az kullandıkları stil hükmetme ve kaçınma olmuştur. Sonuç olarak katılımcıların en fazla algı birliği içinde oldukları stil tümleştirme ve en az algı birliği içerisinde oldukları stiller ise hükmetme ve kaçınmadır. Bununla birlikte katılımcılar çatışma yönetim stillerini kullanım sırasını tümleştirme, uzlaşma, ödün verme, kaçınma ve hükmetme olarak algılamışlardır. Gümüşeli (2004, s. 30-36), çalışmasında okul yöneticilerinin en sık kullandığ1 çatışma yönetim stillerinin kaçınma ve hükmetme; en az kullandıkları stilin ise ödün verme olduğu ortaya çıkmıştır. Buna karşın Özgan'ın (2006, s. 133) çalışmasında ilköğretim okulu öğretmenlerinin çoğunluğunun bütünleştirme stratejisini çok az bir kısmı kaçınma stratejisini kullandığı ortaya çıkmıştır. Akbaba ve Keleş (2015, s. 41) çalı̧smasında okul yöneticilerinin en fazla kullandı̆̆ı çatışma çözme stilinin tümleştirme, en az kullanılan çatışma çözme stilinin ise kaçınma olduğu bulgusuna ulaşmış̧ır. Ayrıca ortaya çıkan bu sonuçlar Gümüşeli (1993), Kunduracioğlu (2008, s. 21), Açıkgöz (2009, s. 9), Uysal (2012, s. 9), Kılıç (2006. S20 ) tarafindan yapılan çalısmalarda yer alan bulgularla benzerlik göstermektedir.

Araştırmada okul yöneticilerinin çatışma yönetiminde kullandıkları stillerin cinsiyet, meslekte geçen süre ve yaşa göre anlamlı bir farklılık olmadığı ancak yönetici olarak meslekte geçen sürede anlamlı bir farklılık olduğu ortaya çıkmıştır. Buna göre 6-10 yıl okul yöneticisi olarak çalışanların 1-5 yll okul yöneticisi olarak çalışanlara göre daha fazla uzlaşma kullandıklarını ortaya koymaktadır. Tunç’un (2011, s. 251) 
çalışmasında ise cinsiyet değişkeninde; erkek katılımcıların, meslektaşları ile çatışmalarını yönetmede hükmetme stilini, kadın katıllımcılara göre daha fazla tercih ettikleri ortaya çıkmışır. Buna karşın Özgan (2006, s. 91), ilköğretim okulu öğretmenlerinin cinsiyetleri ile çatışma yönetimi stratejilerine ilişkin görüşleri arasında, hükmetme ve uyma stratejilerindeki fark anlamlı bir fark olduğunu ancak bütünleştirme, kaçınma ve uzlaşma stratejilerinde anlamlı bir fark olmadığı bulgusuna ulaşmıştır. Özgan'ın (2006, s. 133) çalş̧masında 21 yıl ve daha fazla kıdemi olan öğretmenler 20 yil ve daha az kıdeme sahip olanlara göre bütünleştirme, kaçınma, hükmetme ve uyma stratejilerini daha fazla kullandığı ortaya çıkmıştır.

Okul yöneticilerinin gelir grupları ile çatışma yönetim stillerini kullanma arasında anlamlı bir farklılık olduğu sonucu ortaya çıkmıştır. Buna göre üst gelir grubunda bulunanlar, orta gelir ve orta gelir altında bulunanlara göre hükmetme stilini daha çok kullandığ bulgusu edinilmiştir. Okul yöneticilerinin çatışma yönetiminde kullandıkları stillerin, okuldaki destek personel sayılarına anlamlı bir farklılık olmadı̆̆ı ortaya çıkmışıtır.

Okul yöneticilerinin benlik saygılarının düzeyi \%74 olarak ortaya çıkmışır. Araştırmamızda branş bazında incelendiğinde genel olarak resim öğretmenlerinin benlik saygısı değerleri ortalamanın üzerinde hesaplanmış ancak anlamlı bir farklılık olmadığı bulgusu edinilmiştir. Yıldırım, Kırımoğlu ve Temiz (2010, s. 9), öğretmenlerinin mesleki benlik saygısı düzeylerinin incelediği araştırmasında ilköğretimde görev yapan öğretmenlerle ortaöğretimde görev yapan öğretmenlerin mesleki benlik puanlarının karşılaştırmış ve istatistiksel olarak anlamlı bir farklılık olmadığını tespit etmiştir. Okul yöneticilerinin cinsiyet bağlamında benlik saygısı ölçek değerleri incelendiğinde ortalamalarının birbirine benzer olduğu ancak anlamlı farklılıklar bulunamamıştır. Korkmaz (1996, s. 72) çalışmasında kadınların benlik saygısı toplam puan ortalamaları arasında istatistiksel düzeyde anlamlı farklılaşmanın olduğunu kadınların benlik saygısı erkeklerin benlik saygisının üzerinde gerçekleştiği sonucuna ulaşmıştır.

Yaş değişkenine göre anlamlı bir farklılık gösterip istatistiksel olarak anlamlı bulunmamıştır. Okul yöneticilerinin benlik saygıları ortalamaları meslekte geçen süre gruplarına göre anlamlı bir fark ortaya çıkmamıştır. Yöneticilerin öğretmen olarak geçirmiş oldukları sürelerden 6-10 yıl ve 16-20 yıl çalışanların benlik saygiları ortalaması, $1-5$ yıl ve 21 yl ve üstü yönetici olarak çalışanların ortalamalarından yüksek olarak hesaplanmıştır. Serin (2006) de yapılan çalışmada 11-15 yıl arası öğretmenlik yapanların 6-10 yıl ve 21 yll ve üstü öğretmenlik yapanlardan daha yüksek benlik saygısına sahip oldukları görülmüştür. Okul yöneticilerinin benlik saygıları ortalamaları yönetici olarak geçirdikleri hizmet y1lına ilişkin 6-10 yıl çalısanların benlik saygıları ortalaması, diğer hizmet sürelerinde çalışanların ortalamalarından yüksek olarak hesaplanmıştır.

Okul yöneticilerinin benlik saygıları ölçek ortalamaları gelir gruplarına göre incelendiğinde üst gelirde yer alanların ortalamaları genel ortalamanın altında olduğu bulgusu edinilmiştir. Korkmaz (1996, s. 87), düşük gelire sahip bireylerle, orta düzeyde gelire sahip bireyler arasında benlik sayısı düzeyleri arasında anlamlı bir farklılaşma olduğu bulgusuna ulaşmıştır. Yapılan korelasyon analizi sonuçlarına göre okul yöneticilerinin benlik saygisı ile çatışma yönetimi stilleri üzerinde etkili olduğu sonucuna varılmıştır Benlik saygısı ile tümleştirme ve uzlaşma stilleri arasında anlamlı bir ilişki ortaya çıkmamış buna karşıı kaçınma, ödün verme, hükmetme stilleri arasında pozitif korelasyon ilişkisi ortaya çıkmıştır. Yöneticilerin benlik sayg1 ile en güçlü kolerasyon ilişkisi ödün verme stilinde gerçekleşmiştir. Ödün verme stilinde farkl11ıkların ikinci plana itilerek, ortak yönlerin ön plana çıkarıldığı, karşı tarafin tatmin edilmeye çalışıldığı bir çatışma yönetimi stilidir. Çalışmadaki okul yöneticilerin benlik saygısı yükseldikçe kendi gereksinimlerinin bir kesiminden vazgeçmeyi, karşı tarafin istediğinin bir kesimini yerine getirmeyi tercih ettikleri sonucu çıkmaktadır. Gümüşeli $(1994$, s. 5) ödün verme stilini "uysal birliktelik" olarak adlandırmıştır. Ödün verme stili, karşı tarafla ilişkinin korunması ve sürdürülmesine verilen önemin, ilgilerin ve ihtiyaçların doyurulmasına verilen önemden daha yüksek olduğu durumlarda etkili olabilir. Okul yöneticisi, ilişkinin sürdürülmesine önem veriliyorsa ve karşı tarafla çatışmayı sürdürmek ve çözüm için müzakerelere girişmek karşı tarafla olan ilişkilere zarar verecekse, karşı tarafın isteklerini kabul etmek ve öncelikle karşı tarafı tatmin edecek bir çözümde anlaşmak en uygun seçenek olarak görülebilir (Karip, 2010, s. 15).

Okul yöneticilerin benlik saygısı ile kaçınma ve hükmetme stillerini kullanmaları arasında da ilişki görülmüştür. Kaçınma, sorunu görmezden gelme, sorumluluğu üzerinden atma ile ilişkilendirilir. Çalışmada benlik saygısı ve çatışma stilleri ile ilişkili bir diğer stil ise hükmetme stilidir. Bireyler kendi amaçlarını gerçekleştirmek için başkalarının isteklerini, beklentilerini ve ihtiyaçlarını dikkate almaması, kendilerine yüksek ilgi gösterirken diğerlerine düşük düzeyde ilgi göstermesi, kişinin zararına dahi olsa kendi istek ve arzularını gerçekleştirmek, etrafındakileri boyunduruğu altına almak arzusunda olması gibi 
Özellikleri içerir. Literatür ile karşılaştırma yapıldığında yüksek benlik saygısına sahip bireylerin özellikleri ile tümleştirme ve uzlaştırma stilleri arasında benzerlik gözükmekteydi. Bu nedenle bu iki stil ile benlik saygısı arasında pozitif kolerasyon beklenmekteydi. Fakat bu yapılan çalışma sonucunda tümleştirme ve uzlaşma ile benlik saygısı arasında anlamlı bir kolerasyon bulunmamıştır. Aynı zamanda yüksek benlik saygisına sahip bireylerin özelliklerine ters düşen özellikler taşıyan ödün verme, kaçma ve hükmetme arasında ilişki bulunmuştur.

\section{Öneriler}

Okul yöneticilerinin benlik saygılarının düzeyini arttırması okullardaki çatışma yönetimi konusunda daha etkili olacağı sonucuna ulaşılması idarecilerin çatışma yönetimi alanındaki eksikliklerine de işaret etmektedir.

Yüksek benlik saygısına sahip bireylerin özellikleri ile tümleștirme ve uzlaștırma stilleri arasında anlamlı bir kolerasyon bulunmamış olması ilgililerin yöneticilerin yüksek benlik algısı yönünde eğitimlerine önem vermeleri ve bu alanda hizmet içi eğitime alınmaları önerilebilir.

Çatışma yönetim stilleri ile benlik saygısı arasında pozitif korelasyon olması dolayısıyla, uzun vadede tümleştirme stilinin kullanımının kalıcılı̆̆ı için, okul yöneticilerinin benlik saygısı düzeylerinin arttırılması yönünde eğitimler, bilgilendirme toplantıları, ortak sosyal eğitim etkinlikleri vs. yoluyla yapılabilir.

Benlik saygısı ile çatışma yönetim stilleri arasındaki ilişkiden hareketle, tümleştirme, kaçınma, uzlaşma, ödün verme ve hükmetme stillerinin etkilerinin değerlendirilmesinin, örgütsel çatışmaları yönetmede amaçlanan sonuçlara ulaşmada yararlı olabileceği ifade edilebilir.

Gelecek çalışmalarda benlik saygısı ve çatışma yönetim stilleri arasındaki ilişkilerin farklı örneklemlerde ve farklı eğitim kurumlarında (okulöncesi, lise, üniversite, vs.) tekrarlanması önerilebilir. Farklı eğitim kurumlarındaki farklı pozisyonlardaki öğretmenlerden oluşan örneklemlerde tekrarlanmasının, karşılaştırmalı sonuçlar elde etmede yararlı olacağı düşünülmektedir.

\section{Etik Beyan}

"Ilk ve Ortaokul Yöneticilerinin Catışma Yönetimi Stilleri İe Benlik Saygısı Arasındaki İlişkinin Incelenmesi” başlıklı çalışmanın yazım sürecinde bilimsel, etik ve alıntı kurallarına uyulmuş; toplanan veriler üzerinde herhangi bir tahrifat yapılmamış ve bu çalışma herhangi başka bir akademik yayın ortamına değerlendirme için gönderilmemiştir"

\section{Kaynakça}

Açıkgöz, A. (2009). Okul yöneticilerinin çatısma yönetim stilleri ile ögret-menlerin örgütsel adalet algısı arasındaki ilişki (Yüksek Lisans Tezi). Abant İzzet Baysal Üniversitesi Sosyal Bilimler Enstitüsü, Bolu.

Akbaba, A. ve Keleş, E. (2015). İlk ve ortaokul müdürlerinin çatışma yönetim stratejilerine ilişkin öğretmen algıları, International Journal of Social Science, 31, 21-43.

Atay, K. (2001). Okul müdürlerinin çatışmaları çözümleme stratejilerine ilişkin öğretmen, okul müdürü ve denetmen alg1lar1. Kuram ve Uygulamada Eğitim Yönetimi Dergisi, 7(25), 21-31.

Bridge, B. (2003). Eğitimde vizyoner liderlik ve etkin yöneticilik. İstanbul: Beyaz Yayınları.

Büyükşahin C, G. (2017). Üniversite öğrencilerinin toplumsal cinsiyet rolleri ve çatıșma çözme stillerinin incelenmesi. Mersin Üniversitesi Eğitim Fakültesi Dergisi, 13(3), 1017-1034. DOI: 10,17860/mersinefd.320021

Erçetin, Ş. (2000). Lider sarmalında vizyon (2.Baski). Ankara: Nobel Dağıtım.

Gravetter, F. ve Wallnau, L. (2014). Essentials of statistics for the behavioral sciences (8 $8^{\text {th }}$ Edition). Belmont, CA: Wadsworth.

Gümüşeli, A. İ. (1994). İzmir ortaöğretim okullar yöneticilerinin ögrretmenlerle aralarndaki çatısmalar yönetme biçimleri (Doktora Tezi). Ankara Üniversitesi Sosyal Bilimler Enstitüsü, Ankara.

Karasar, N. (2012). Araştırmalarda rapor haz̨rlama. Ankara: Nobel Yayın Dağıtım.

Kılıç, S. (2006). Öz̧el okul ögretmenlerinin çatışma yaklaşımlar ile çatısmayn yönetme stilleri (Yüksek Lisans Tezi). Sosyal Bilimler Enstitüsü, İstanbul.

Kıngır. S. \& Okçu, V (2011). Etik liderlik, yönetimde çăgdaș ve güncel konular (Edt: İ. Bakan). Ankara: Gazi Kitabevi

Koçel, T. (2007). İsletme yöneticiliği, yönetim ve organizasyon-organizasyonlarda davranıs-klasik-modern-çağdaş yaklaşımlar. İstanbul.

Korkmaz, M. (1994). Yetişkin örneklem için bir benlik saygısı ölçeğinin güvenirlik ve geçerlik çalışması (Yüksek Lisans Tezi). Ege Üniversitesi, Sosyal Bilimler Enstitüsü, İzmir.

Özdemir, S. (1998). Eğitimde örgütsel yenileșme. Ankara: Pegem Yayınc1lik. 
Özgan, H. (2006). İlköğretim okulu ögretmenlerinin çatısma yönetimi stratejilerinin incelenmesi (Gaz̧iantep Örneğ̊) (Yüksek Lisans Tezi). Gaziantep Üniversitesi, Eğitim Bilimleri Enstitüsü, Gaziantep.

Rahim M. A. (1983). Rabim organizational conflict inventories: professional manual. Palo Alto, CA: Consulting Psychologists Pres.

Tezcan Ö, S. (2017). Okul müdürlerinin çatışma yönetimi stratejileri ve iletişim tar:̧larna yönelik öğretmen görüsleri. http://dspace.trakya.edu.tr/xmlui/handle/1/2753

Tufan, B. \& Süleyman Y. (1993). Geri dönüss sürecinde ikinci kuşak. Ankara: Hacettepe Üniversitesi Yayınlar1

Yalçın, S. (2018). 21. yüzyıl becerileri ve bu becerilerin ölçülmesinde kullanılan araçlar ve yaklaşımlar. Ankara Üniversitesi Ë̆itim Bilimleri Fakültesi Dergisi, 51(1), 183-201. DOI: 10,30964/auebfd.405860

Yalım, F. E. (2001). Yüksekëğretim ögrencilerinde benlik saygısınn akademik başar ve ana-baba ilişkisi (Yüksek Lisans Tezi). Kocaeli Üniversitesi, İstanbul.

Yaşar, T. (2020). Yaşar Kemal'ın 'İnce Memed.1' ve Kemal Tahir'ın 'Rahmet Yolları Kesti' adlı eserlerinde çocuk eşk1yalar. International Social Sciences Studies Journal, 6(62), 21-64.

Yörükoğlu, A. (1993). Gençlik çă̆ı rub sağh̆ğ ve rubsal sorunlar (8. Baskı). İstanbul: Özgür Yayınları.

\section{EXTENDED ABSTRACT}

The study was conducted to determine the relationship between conflict management styles and self-esteem of school administrators working in primary and secondary schools in Antalya province. The research universe is composed of the primary and secondary school managers in Antalya province and the study universe consists of the primary and secondary school managers in Serik and Manavgat districts. In Serik and Manavgat districts, the research was carried out with the participation of 241 people from the school administrators working in 179 official primary and secondary schools. In the research, the entire universe was tried to be reached. In the research "personal information form", "Trakya University selfesteem scale" and "Rahim organizational conflict Scale" were used as data collection tools. Research, Data Analysis, Percentage, arithmetic mean, standard deviation, t-test, one-way ANOVA test, Tukey test were used. The significance level was based on 0.05 level.

As a result of the analysis of research data, conflict management styles and self-esteem of the managers have been determined. Conflict management styles and self-esteem scale values used by school principals; age, gender, branch, year of service, year of service as being an administrator, income group, number of teachers and support staff at school were analyzed. However, the relationship between selfesteem scale values and conflict management styles of school principals was also analyzed. As a result of the analysis belongs to the research data, variables such as age, gender, branch, year of service, year of service as administrator, graduate education status, income group, number of teachers and support staff at school, management-related education, conflict management strategies and self-esteem were found to be different.

In this study, the distribution of conflict management styles of primary and secondary school administrators, the levels of self-esteem and the relationship between conflict management styles and selfesteem were investigated. With these perceptions, it is important to present the recommendations of educational managers and planners to reveal the differences between the distribution of conflict management styles of primary and secondary school administrators and to find out whether there are significant differences between the variables.

In this part of the research, research model, universe and sample, data collection technique and analysis are explained. In addition, this section includes information about the conflict management styles scale and self-esteem scale used in the research.

Research model is a study. This research, which aims to determine the relationship between conflict management styles and self-esteem of primary and secondary school administrators, examines the present situation and the descriptive and relational screening model that are used. (Büyüköztürk et al, 2009; Erkuş, 2005; Karasar, 2002), In this study, the relationship between self-esteem and conflict management styles of primary and secondary school administrators was examined. In addition, managers; As it is aimed to examine whether gender, age, branch, year of service as teacher, year of service as education manager, school support staff and perceived income levels differ, general screening model, which is the most suitable model for this purpose, was used.

As a result of the analysis of research data, conflict management styles and self-esteem of the managers have been determined. Conflict management styles and self-esteem scale values used by school principals; age, gender, branch, year of service, year of service as being an administrator, income group, number of teachers and support staff at school were analyzed. However, the relationship between self- 
esteem scale values and conflict management styles of school principals was also analyzed. As a result of the analysis of the research data, variables such as age, gender, branch, year of service, year of service as being an administrator, graduate education status, income group, number of teachers and support staff at school, management-related education, conflict management strategies and self-esteem were found to be different.

In addition, there was a relationship between school principals' self-esteem and avoidance and dominance styles. Avoidance is associated with ignoring the problem and dismissing the responsibility. Another style associated with self-esteem and conflict styles is dominating style. Individuals include features such as not taking the wishes into account, expectations and needs of others in order to realize their own goals, showing high interest to others while showing low interest to others, performing their own desires and desires which are even to the detriment of the person, and the desire to subjugate those around them. When compared with the literature, there was a similarity between the characteristics of individuals with high self-esteem and their integration and mediation styles. Therefore, a positive correlation between these two styles and self-esteem was expected. However, no significant correlation was found between integration and reconciliation and self-esteem. At the same time, a relationship was found between concession, escaping and dominating with characteristics that contradict the characteristics of individuals with high self-esteem. 